\title{
Nutrient Cycling in Primary, Secondary Forests and Cocoa Plantation in the Ashanti Region, Ghana
}

\author{
E. Owusu-Sekyere ${ }^{1 *}$, J. Cobbina ${ }^{1}$ and T. Wakatsuki ${ }^{2}$ \\ ${ }^{1}$ Forestry Research Institute of Ghana (FORIG), UP 63, KNUST, Kumasi, Ghana \\ ${ }^{2}$ Faculty of Agriculture, Kinki University, Nara 631-8505, Japan \\ *Corresponding author, E-mail: eosekyere@forig.org
}

\begin{abstract}
Primary forest (reserved area), secondary forest and cocoa plantation land uses characterize uplands of Dwinyama watershed in Ghana within the dry semi-deciduous forest zone. The nutrients recycled in the land uses were studied through leaf litter fall, nutrient release, nutrient fluxes estimation and topsoil nutrient contents leading to the identification of appropriate land use in upland regions that may potentially influence lowland farming. Mean annual leaf litter produced by the primary and secondary forests was both $7.9 \mathrm{t} \mathrm{ha}^{-1}$ and that for cocoa plantation was $6.9 \mathrm{t} \mathrm{ha}^{-1}$. The primary forest leaf litter showed rapid decomposition than the secondary forest and the cocoa leaf litter. Nutrients released from the decomposing leaf litters were fast for N, P, K, Ca and Mg for the primary and secondary forests. Less leaf litter production and high rainfall regimes in South America and southeast Asia probably contributed to the lower annual nutrient fluxes recorded than that of the dry semi-deciduous tropical forest in Ghana. The soil under cocoa plantation was higher in Ca than in the secondary and primary forests soils. The primary forest recorded higher contents of top soil N, P. K, and Mg nutrients due to non-frequent removal of the vegetation, presence of organic matter that increases soil carbon content and cation exchange capacity. Generally, trends of nutrients released and the quantities of nutrient fluxes estimate in the land uses in Ghana suggested that nutrient cycling was better in the primary forest followed by the secondary forest and cocoa plantation. The trend in the land uses was primary > secondary > cocoa, suggesting that forests in uplands will protect watersheds, and, through leaching and erosion, nutrients may be transported to the lowlands for continuous and sustainable cropping with little or no inorganic fertilizer application.
\end{abstract}

\section{Introduction}

Dwinyan watershed belongs to the tropical semi-deciduous dry forest in the Ashanti Region. The watershed is characterized by primary forest in the upland (reserved area), secondary forest in the middle, and lower slopes and cultivated areas extend from the middle slope to the lowlands. The cultivated areas are cocoa plantations, mixed crop farms and young herbaceous and/or shrubby fallows. Law protects the primary forest and entry is by permit obtained from Ghana Forestry Commission. Permits are granted to harvest only timber tree species periodically. However, fringe community members illegally enter the forest to harvest game, non-timber forest products and sometimes timber. In Ghana, non-reserved primary forests are often cleared to establish farms by slash-and-burn for a short period of 2-3 years and allowed to fallow when soil fertility declines. Tree crops such as cocoa plantations occupy the land for a reasonably long time after clearing.

In each of the land uses, plants absorb nutrients for the manufacture of food, meta-bolic processes, assimilation, maintenance and reproduction for sustainability. The nutrients are returned to the soil through litter fall, decomposes to release mineral nutrients for re-absorption. Hirose \& Wakatsuki (1997) stated that nutrients being recycled within land use systems in the uplands may be carried down the topo-sequence through erosion and leaching to the lowlands to influence the soils of the valley bottoms. Until recently, lowlands of watersheds were used for upland and valley bottom rice cultivation during the rainy season, and vegetables in the valley bottoms during the dry season by poor farmers at subsistent level. Utilization of the lowland areas for commercial crop production of rice and vegetables is now encouraged to reduce rural poverty. Fertility declines with intensive continuous cropping of lowlands. Therefore, fertilizer use is recorded to be high recently to increase and sustain crop production levels.

The cost of fertilizer is high and many of the peasant farmers cannot afford its use. Alternative sources of fertilization at minimal cost would be of great relief to these farmers. Very little information is available on the nutrient cycling in various land uses of watersheds in Ghana. Leaves play major role in the manufacturing of food and storage of nutrient. They drop to the forest floor and decompose to release the stored nutrients for re-absorption. Therefore, it was the objective of this study to identify which land use of the upland in the watershed that would

Volume 9 (Jan - Jun 2006)

Page 1 of 9 
recycle nutrients better through nutrients releases from the leaf litters and to estimate the fluxes of the nutrients in the land uses between the litter materials and the soil surface so as to assess the potential to influence the fertility of the lowland soils. This information will lead to the identification of appropriate land use in upland regions that may have the potential to influence and probably reduce chemical fertilizer use during lowland farming.

\section{Materials and methods}

Primary forest (Tinte-Bepo Forest Reserve), secondary forest and cocoa plantation located on both the same latitudes $\left(6^{\circ} 33^{\prime}\right.$ and $\left.7^{\circ} 03^{\prime} \mathrm{N}\right)$ and longitudes $\left(1^{\circ} 55\right.$ and $\left.2^{\circ} 06 \mathrm{~W}\right)$ were selected for the study. The total area of the primary forest (PF) covering 12,000 ha was dominated by Celtis and Triplochiton tree species and the eastern block where the study was conducted covered 2,900 ha. Akyaakrom Secondary Forest (ASF) located $80 \mathrm{~m}$ south of the primary forest, covered 30 ha and the dominant tree species was Griffornia simplicifolia. Dopiri Cocoa Plantation (DCP) was located about $7 \mathrm{~km}$ south of the primary forest (Fig. 1). It was a pure stand of cocoa trees devoid of other tree species. The soils under the primary forest belonged to the Bekwai series which is classified as Ferric Acrisols (ISSS, 1994). The ASF and DCP land uses belonged to the Nzima series and are classified as Ferric Lixisol (ISSS, 1994). 


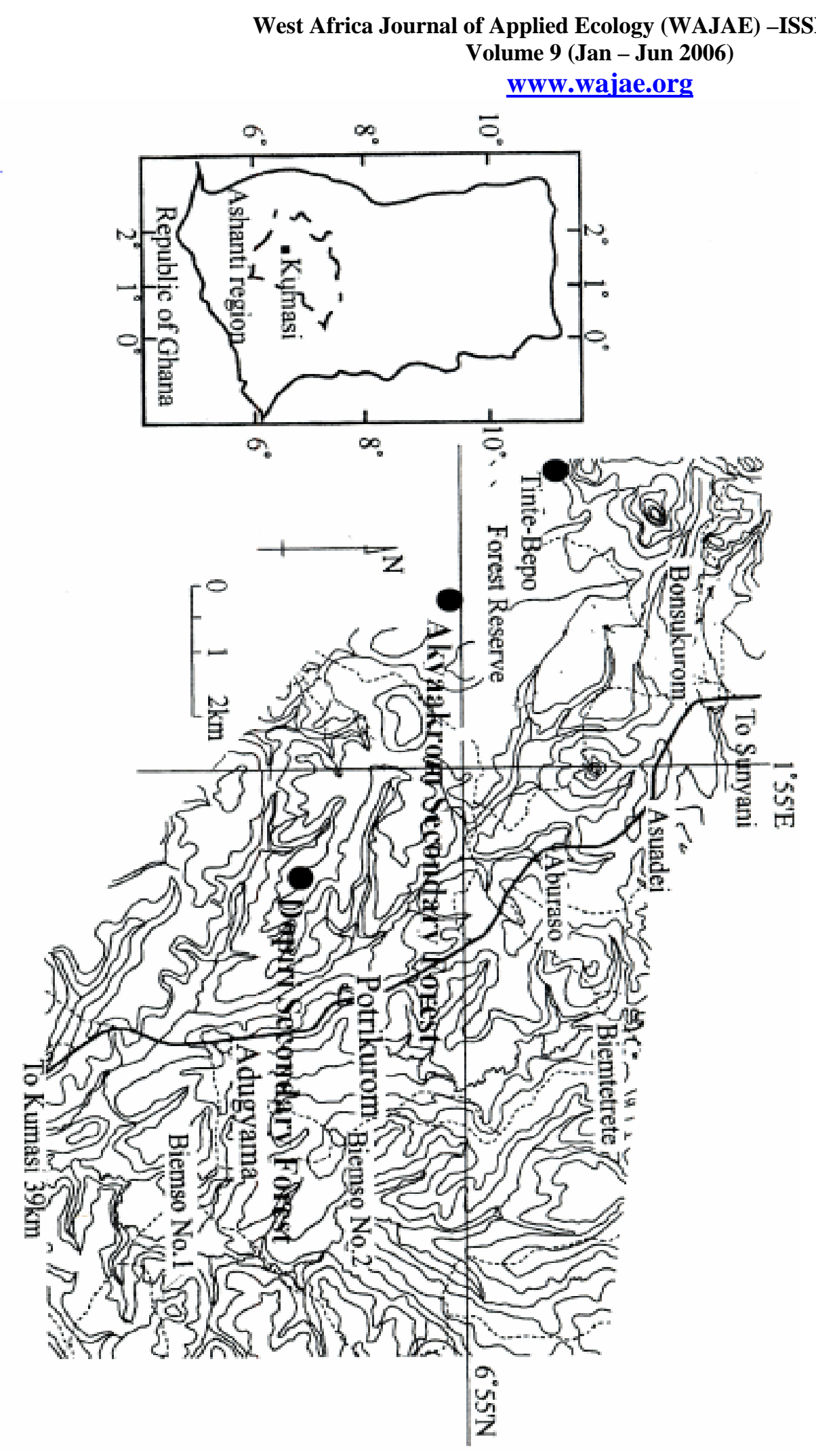

Fig. 1. The location of primary forest (Tinte-Bepo Forest Reserve- T-BFR,), Akyaakrom (AS) and Dopiri (DS) secondary forests in Dwinyan Watershed 


\section{West Africa Journal of Applied Ecology (WAJAE) -ISSN: 0855-4307 \\ Volume 9 (Jan - Jun 2006) \\ www.wajae.org}

Nine litter traps made of square wooden frame $(1.0 \times 1.0 \mathrm{~m}$ inner surface dimension) raised $1.0 \mathrm{~m}$ above the soil surfaces were erected in each land use. To collect the falling litter, nylon mesh of size $2 \mathrm{~mm}$ were secured on the frame and allowed to sag below but not touching the forest floor. The fallen litter in each trap was collected every 14 days. The leaf portion was sorted out from the total trapped litter, dried in the oven at $60{ }^{\circ} \mathrm{C}$ for $72 \mathrm{~h}$ and weighed for each trap. The collections began in September 1998 and continued till August 2000.

Decomposition boxes made of Melicia excelsa wooden frames [20.0 cm $\times 20.0 \mathrm{~cm}$ (inner surface dimension) 2.0 $\mathrm{cm}$ deep and $0.5 \mathrm{~cm}$ thickness] were used. Galvanized wire mesh $(1.0 \mathrm{~mm})$ was passed around the frame to exclude larger decomposing organisms and minimize loss of leaves after fragmentation. Ten grams of oven-leaf litter were transferred into each decomposition boxes and placed on the soil surface in the various land uses. Three boxes were sampled from each land use every 28 days. The monthly partially decomposed leaf litter was carefully cleaned from plant roots, soil particles and other material and oven-dried at $60{ }^{\circ} \mathrm{C}$ for $72 \mathrm{~h}$ to prevent further decay before leaf-litter nutrients were analysed.

\section{Soil sampling}

Composite topsoil $(0-10 \mathrm{~cm})$ samples were randomly collected from the primary forest, secondary forest and the cocoa plantation by using auger. The soil samples were air-dried, screened through 2-mm sieve for selected chemical analysis. The plant and soil samples were milled separately using a tungsten carbide vibrating mixer mill (MRK-Retsch Mitamura Rikon Kogyo 18-34). The plant samples were digested by the wet oxidation method using $\mathrm{HNO}_{3}$ in Teflon jars under pressure at $150{ }^{\circ} \mathrm{C}$ for $4 \mathrm{~h}$ in the oven. Exchangeable $\mathrm{Ca}$ and $\mathrm{Mg}$ concentrations were first extracted with ammonium acetate (1.0 $\mathrm{M} \mathrm{NH}_{4} \mathrm{OAc}$ ). Phosphorus in plant, $\mathrm{Ca}$ and $\mathrm{Mg}$ concentrations of the plant and soil samples were determined using inductively coupled plasma-atomic emission spectroscopy (ICPS2000, Shimadzu Co.) Total $\mathrm{N}$ in the samples was determined by dry combustion using Sumigraph N-C 90A Analyzer (Sumitomo Chemical). Available phosphorus in the soil was determined by the Bray-1 method (Bray \& Kurtz, 1945). Exchangeable $\mathrm{K}$ in the samples was determined by atomic absorption spectrophotometry. Soil $p \mathrm{H}$ $\left(\mathrm{H}_{2} \mathrm{O}\right)$ was determined using $p \mathrm{H}$ meter (with glass electrode).

\section{Data analyses}

Monthly rainfall and leaf litter production for each land use were compared on a graph. Nutrients releases were calculated from the differences in monthly residual nutrient concentrations and the residual nutrient concentrations of preceding month and trends were compared in graphs. The products of monthly nutrient released and monthly leaf litter for each element represented the monthly nutrient fluxes for each of the land uses. The sum of monthly nutrient fluxes for 12 months were calculated as the annual fluxes. The results obtained were compared with those obtained for some Southeast Asian and South American countries. Statistical analyses were per-formed using SAS/Start View (SAS, 1999).

\section{Results and discussion}

Annual leaf litter produced by the primary and secondary forests was $7.9 \mathrm{t} \mathrm{ha}^{-1}$ in each land use (Table 1). The values obtained were higher than $5.4 \mathrm{t} \mathrm{ha}^{-1}$ previously reported by Klinge (1974) in Malaysia. John (1973) obtained $7.4 \mathrm{t} \mathrm{ha}^{-1}$ year $^{-1}$ for tropical semi-deciduous forest leaf litter in Ghana (O’Neill \& DeAngelis, 1980); Gong \& Ong, 1983; Lugo, 1991). Proctor et al (1983) recorded $5.4 \mathrm{t} \mathrm{ha}^{-1}$ year-1 for Southeast Asian dipterocarp forest, Brouwer (1996) recorded $7.1 \mathrm{t} \mathrm{ha}^{-1}$ year-1 $^{-1}$ for Surinam, and Cuevas \& Medina (1986) recorded $7.6 \mathrm{t} \mathrm{ha}^{-1}$ year $^{-1}$ for Venezuela (South American tropical high forests). Forest vegetation composition types and high annual rainfall quantities in South America and Southeast Asia may have accounted for the lower leaf litter fall. The cocoa plantation produced the least annual litter of $6.9 \mathrm{t} \mathrm{ha}^{-1}$ but was higher than that recorded for Malaysia (Table 1). The leaf litter production were highest in the dry (December-February) in each year (Fig. 2). 
West Africa Journal of Applied Ecology (WAJAE) -ISSN: 0855-4307

Volume 9 (Jan - Jun 2006)

www.wajae.org

TABLE 1

Mean annual rainfalls, leaf litter productions and nutrient fluxes in a dry semi-deciduous tropical forest (PF), Akyaakrom secondary forest (ASF) and Dopiri Cocoa Plantation (DCP) land uses in Dwinyan watershed, Ghana compared with wet tropical high forest of Surinam and Venezuela (South America) and Malaysia in southeast Asia

\begin{tabular}{|c|c|c|c|c|c|c|c|}
\hline \multirow[t]{2}{*}{ Land use } & \multirow{2}{*}{$\begin{array}{l}\text { Rainfall } \\
\left(m m y^{-1}\right)\end{array}$} & \multirow{2}{*}{$\begin{array}{l}\text { Leaf litter } \\
\left(t h a^{-1} y^{-1}\right)\end{array}$} & \multirow[b]{2}{*}{$N$} & \multicolumn{4}{|c|}{ Nutrient fluxes (t ha- $\left.y^{-1}\right)$} \\
\hline & & & & $P$ & K & $\mathrm{Ca}$ & $M g$ \\
\hline $\mathrm{PF}$ & 1600 & 7.9 & 166 & 7.2 & 31.6 & 156.6 & 23.0 \\
\hline ASF & 1600 & 7.9 & 172 & 5.6 & 44.1 & 118.6 & 19.4 \\
\hline DCP & 1600 & 6.9 & 104 & 6.7 & 15.8 & 94.8 & 7.3 \\
\hline${ }^{\mathrm{a}}$ Malaysia & 5100 & 5.4 & 95.0 & 1.1 & 45.0 & 15.0 & 11.0 \\
\hline${ }^{\mathrm{b}}$ Surinam ${ }^{\mathrm{a}}$ & 2200 & 7.1 & 144.0 & 4.0 & 31.0 & 61.0 & 22.0 \\
\hline${ }^{\mathrm{c}}$ Venezuela & 3500 & 7.6 & 162.0 & 3.2 & 24.0 & 17.0 & 7.0 \\
\hline
\end{tabular}

Wet tropical high forest in some southeast Asia and South American countries.

aProctor et al., 1983; 'bchmidth quoted by Brouwer, 1996; 'Cuevas \& Medina, 1986.

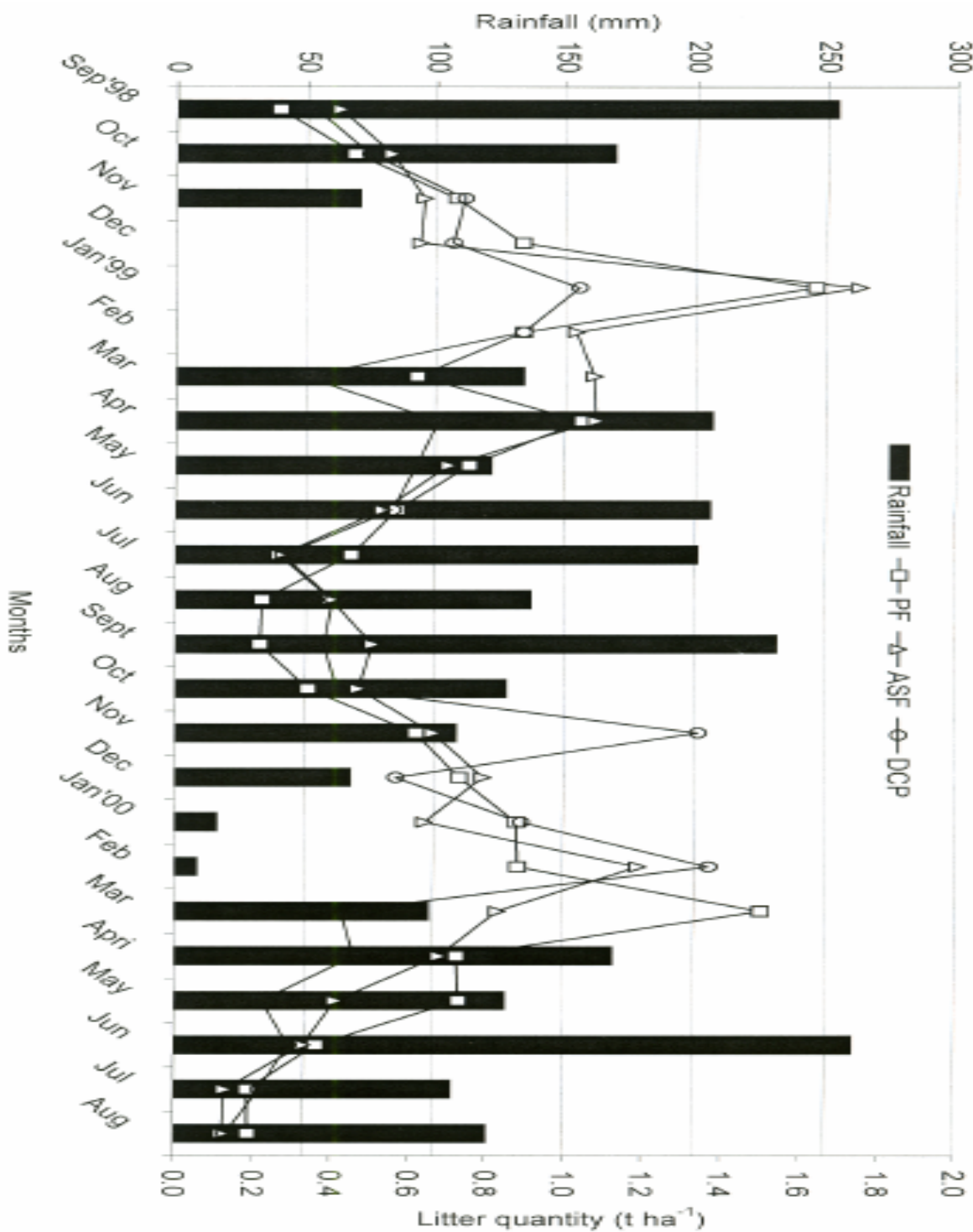

Volume 9 (Jan - Jun 2006)

Page 5 of 9 


\section{West Africa Journal of Applied Ecology (WAJAE) -ISSN: 0855-4307 \\ Volume 9 (Jan - Jun 2006) \\ www.wajae.org}

Fig. 2. Monthly rainfall (mm) and leaf litter fall $\left(\mathrm{t} \mathrm{ha} \mathrm{h}^{-1}\right)$ recorded over 2 years (Sep. 1999-Aug. 2000) from primary (PF), secondary (ASF) forests and cocoa plantation (DCP) in Dwinyama Watershed in the Ashanti Region, Ghana.

The quantities of leaf litter produced in each year cycle were different. In the first year cycle, i.e. September 1998August 1999, the annual leaf litter productions were 8.5, 9.1 and $7.1 \mathrm{t} \mathrm{ha}^{-1}$ for primary and secondary forests, and cocoa plantation, respectively, and the total annual rainfall was about $1500 \mathrm{~mm}$. During the second year cycle, i.e. September 1999-August 2000, annual precipitation decreased to about $1400 \mathrm{~mm}$, leaf litter productions also reduced in the three land uses, i.e. $7.4 \mathrm{t} \mathrm{ha}^{-1}$ for the primary forest, $6.8 \mathrm{t} \mathrm{ha}^{-1}$ for the secondary forest and $6.7 \mathrm{t} \mathrm{ha}^{-1}$ for the cocoa plantation (Fig. 2). In the drier months, total precipita-tion of $4.5 \%$ of the annual total was recorded between December 1998-February 1999 in year one and increased to 6.4\% in year two (December 1999-February 2000), representing an increase of $1.1 \%$ rainfall in year two. Within the same dry months (December-February in each year), there were decreases of $27 \%, 23 \%$ and $30 \%$ leaf litter fall production from the primary and secondary forests, and cocoa plantation, respectively, in year two when rainfall increased by 1.1\% (Fig. 2).

Fig. 3a shows the loss of decomposition leaf litter of the land uses. Decomposition of leaf litter from primary and secondary forests were relatively faster than that of cocoa leaf litter. The PF leaf litter showed rapid decomposition as compared to ASF even though leaf litter of the latter was dominated by a legume G. simplicifolia tree species. Leguminous tree species are known to decompose faster but soil and forest floor microorganisms play a significant role in decomposition (Swift et al., 1979). The population of microorganisms may have been greater in PF environment than in ASF, and were probably responsible for the faster decomposition in PF. Decomposition was completed within a year cycle for the forests leaf litter (primary and secon-dary). Cocoa leaf litter, however, decomposed at a slow rate and extended beyond 12 months (Fig. 3a).

Nutrients released from the decomposing leaf litters were fast for $\mathrm{N}, \mathrm{P}, \mathrm{K}, \mathrm{Ca}$ and $\mathrm{Mg}$ for primary and secondary forests leaf litter (Figs, 3b, c, d, e and f, respectively). In the Cocoa plantation, except P (Fig. 3c), the other nutrients were released gradually than the loss of decomposing leaf material. The release of $\mathrm{N}, \mathrm{K}$, Ca and $\mathrm{Mg}$ from DCP leaf litter was comparatively slower and amounts were lower than those released from the forest land uses (Fig. 3a, b, d, e and $\mathrm{f}$ ). The releases of $\mathrm{N}, \mathrm{P}, \mathrm{Ca}$ and $\mathrm{Mg}$ of secondary forest were characterized by fluctuations in the initial 6 months of exposure to decomposition (Fig. 3b, c, e and f, respec-tively) and almost all the nutrients were released before the 8th exposure month except for $\mathrm{N}$ from ASF (Fig. 3b). 
West Africa Journal of Applied Ecology (WAJAE) -ISSN: 0855-4307

Volume 9 (Jan - Jun 2006)

www.wajae.org
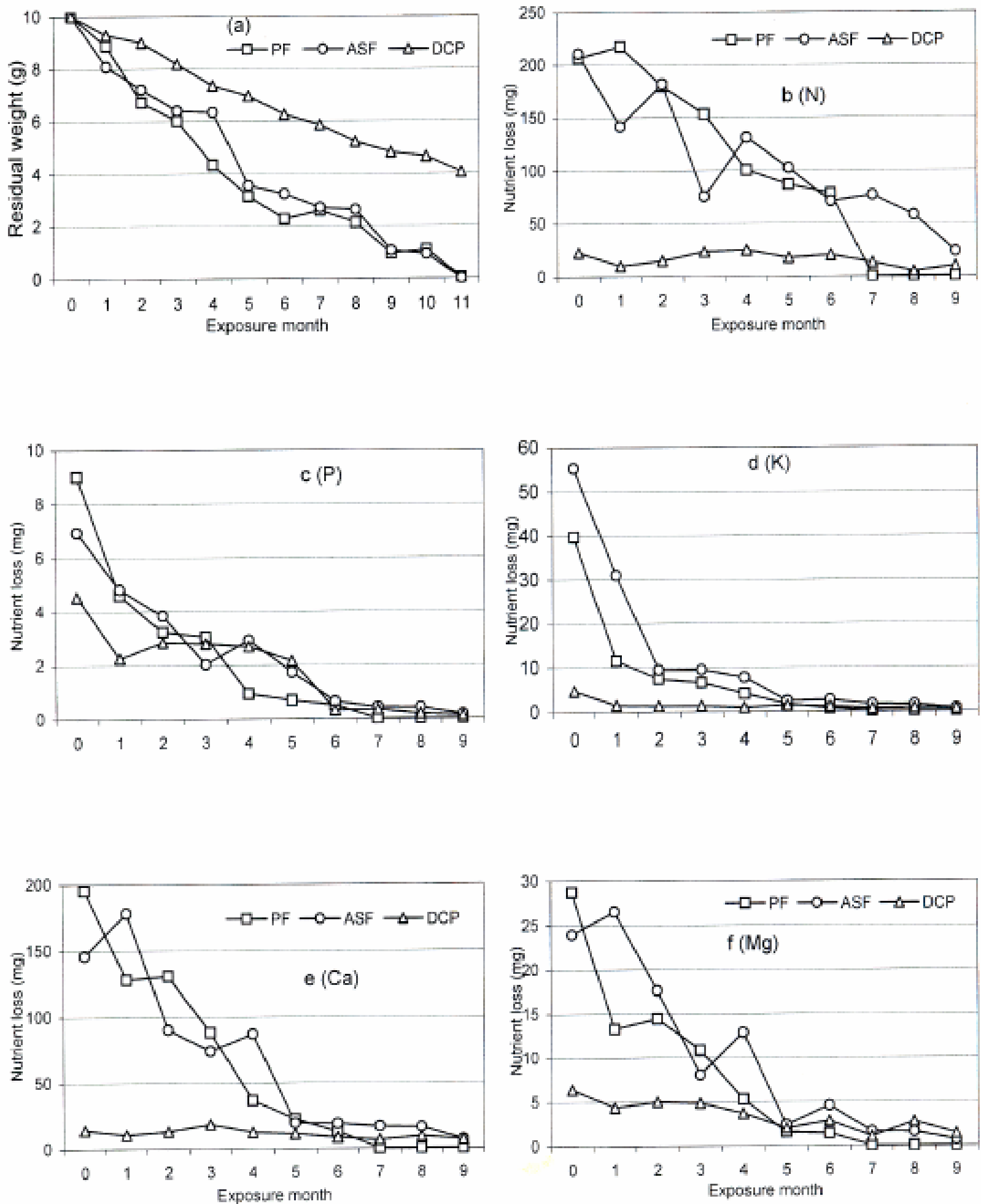

Fig. 3. Residual weight (g) (a) and nutrient loss (mg) (b-f) from residual leaf litters: initial weight was $10 \mathrm{~g}$ 


\section{West Africa Journal of Applied Ecology (WAJAE) -ISSN: 0855-4307 \\ Volume 9 (Jan - Jun 2006) \\ www.wajae.org}

The mean annual nutrient fluxes estimated for the land uses is presented in Table 1. The annual nutrient fluxes of $\mathrm{P}$ ( $\left.7 \mathrm{t} \mathrm{ha}^{-1}\right)$, Ca (157 t ha-1) and Mg (23 t ha ${ }^{-1}$ ) were highest for PF representing 36.9\%, 42.3\% and 46.3\% of the total, respectively. In ASF, $\mathrm{N}\left(172 \mathrm{t} \mathrm{ha}^{-1}\right)$ and $\mathrm{K}\left(44 \mathrm{t} \mathrm{ha}^{-1}\right)$ fluxes were the highest constituting $38.9 \%$ and $48.2 \%$ of the total. In the cocoa plantation, fluxes of $\mathrm{N}\left(104 \mathrm{t} \mathrm{ha}^{-1}, 23.5 \%\right), \mathrm{K}\left(16 \mathrm{t} \mathrm{ha}^{-1}, 17.3 \%\right)$, Ca $\left.95 \mathrm{t} \mathrm{ha}^{-1}, 26.6 \%\right)$ and $\mathrm{Mg}(4 \mathrm{t}$ $\mathrm{ha}^{-1}, 18.7 \%$ ) were least but $\mathrm{P}$ flux $\left.7 \mathrm{t} \mathrm{ha}^{-1}, 34.4 \%\right)$ was higher than that of the secondary forest (6 $\left.\mathrm{t} \mathrm{ha}^{-1}, 28.7 \%\right)$. Fluxes of N (37.6\%) and K (37.5\%) were lower than ASF. Generally, trends of nutrients released (Fig. 3b, c, d, e and $\mathrm{f}$ ) and the quantities of nutrient fluxes estimate in the land uses (Table 1) suggested that nutrient cycling may be better in the order of primary > secondary > cocoa land uses of Dwinyama watershed in Ghana.

Comparing the nutrient fluxes obtained in wet tropical forests of South America and southeast Asia, it was observed that nutrient fluxes were generally lower in the wet tropical forests than in the dry semi-deciduous tropical forest in Ghana. The fluxes of N, P, Ca and Mg in the wet tropical forests were low more especially P and Ca (Table 1). The higher precipitation in the wet tropical forests might have leached out the nutrients. Less leaf litter production was obtained for South America and southeast Asia due to higher precipitation and, therefore, less annual nutrient fluxes were recorded. Conversely, the lower amount and distribution of precipitation in Ghana (Fig. 2) contributed to high leaf litter fall as reported by Gong \& Ong (1983), Owusu-Sekyere et al. (2003) and subsequently contributing to the higher nutrient fluxes obtained in Table 1.

The $p \mathrm{H}\left(\mathrm{H}_{2} \mathrm{O}\right)$ of the soils in the land uses ranged between 6.0-6.2, slightly acidic (Table 2). The soil under the cocoa plantation was higher in Ca $\left(91.8 \mathrm{cmol}_{\mathrm{c}} \mathrm{kg}^{-1}\right)$ than in secondary and primary forest (55.2 and $28.6 \mathrm{cmol}_{\mathrm{c}} \mathrm{kg}^{-1}$, respectively). The large amount of organic matter mat formed by the cocoa leaf litter prevented rapid leaching of the Ca nutrient. Total carbon was higher in PF $\left(43 \mathrm{~g} \mathrm{~kg}^{-1}\right)$ and DCP $\left(32 \mathrm{~g} \mathrm{~kg}^{-1}\right)$ was higher than in ASF $\left(24 \mathrm{~g} \mathrm{~kg}^{-1}\right)$. Concentration of $\mathrm{K}$ in PF was higher $\left(2.2 \mathrm{cmol}_{\mathrm{c}} \mathrm{kg}^{-1}\right)$ than ASF $\left(1.6 \mathrm{cmol}_{\mathrm{c}} \mathrm{kg}^{-1}\right)$ and DCP $\left(1.8 \mathrm{cmol}_{\mathrm{c}} \mathrm{kg}^{-1}\right)$ (Table 2). The thick organic layer might have prevented loss of N, P and Mg through leaching under the cocoa plantation. The loss of cocoa leaf litter material during decomposition and the resultant organic matter build-up on the soil surface might have served as sinks for the nutrients.

TABLE 2

Top soil fertility levels in primary (PF), secondary (ASF) forests and cocoa plantation (DCP) in Dwinyan Watershed

\begin{tabular}{|c|c|c|c|c|c|c|c|c|}
\hline Land use & $\mathrm{pH}\left(\mathrm{H}_{2} \mathrm{O}\right)$ & $T C$ & $\begin{array}{c}T N \\
g k^{-1}\end{array}$ & $A v . P\left(m g k g^{-1}\right)$ & K & $\begin{array}{l}\mathrm{Ca} \\
\text { (cmol }\end{array}$ & $\begin{array}{l}M g \\
\left.g^{-1}\right)\end{array}$ & $E C$ \\
\hline $\mathrm{PF}$ & 6.2 & 43 (a) & 4.4 (a) & 1.18 (a) & 2.18 (a) & 28.59 (a) & 8.63 (a) & $14.08(\mathrm{a})$ \\
\hline ASF & 6.0 & 24 (c) & 2.7 (b) & 1.32 (a) & 1.64 (b) & 55.21 (b) & 6.49 (a) & $10.01(b)$ \\
\hline DCP & 6.1 & 32 (b) & 3.4 (a) & $1.06(\mathrm{a})$ & 1.84 (b) & 91.81 (c) & 3.49 (b) & $12.96(\mathrm{c})$ \\
\hline
\end{tabular}

The same letters in parenthesis within a column were not significantly different at $\mathrm{P}<0.05$.

Available $\mathrm{P}$ contents of the soil were relatively very low and the highest topsoil content of $1.32 \mathrm{mg} \mathrm{kg}^{-1}$ was recorded for ASF and least for DCP (1.06 mg kg-1). Higher contents of N, P, K, Ca and Mg and the level of eCEC were recorded for the land uses. The primary forest recorded higher contents of top soil $\mathrm{N}, \mathrm{K}$, and $\mathrm{Mg}$ nutrients. The trend of nutrient content in decreasing order in the land uses was primary > secondary > cocoa. Anna-Afful et al. (2004) observed that land uses located in upland areas have higher nutrient contents than the lowlands and this observation was attributed to non-removal of vegetation of the land uses. When forests are converted into croplands, the organic layer is depleted and requires time to build up again. The soil carbon content and cation exchange capacity may also decrease (Manu et al., 1997; Watson et al., 2000; Brady \& Weil, 2002). 


\section{West Africa Journal of Applied Ecology (WAJAE) -ISSN: 0855-4307 \\ Volume 9 (Jan - Jun 2006) \\ www.wajae.org \\ Conclusion}

Leaf litter production was higher in dry season and higher in the dry semi-deciduous tropical forest than wet tropical forests of South America and South-east Asia. Leaf litter produced differed from year to year in all the land uses. Mean annual leaf litter produced was higher in the primary and secondary forests than in the cocoa plantation. Primary and secondary forests leaf litter decomposed and mineralized faster than that of the cocoa plantation.

Decomposition of cocoa leaves was slow and extended beyond 12 months. Primary forest tree species leaf litter returned much more nutrients and topsoil was higher in nutrient contents than the secondary forest and cocoa plantation. Nutrient cycling seemed better in the primary forest followed by the secondary forest and the cocoa plantation based on loss of leaf litter material, nutrient released and estimated nutrient fluxes. Therefore, forests may be encouraged in uplands to protect and increase the return of nutrients that may be transported through leaching and run-off to increase or influence nutrient levels in the lowlands for continuous cropping with little or no inorganic fertilizer application.

\section{Acknowledgement}

The authors wish to thank the Ghana Forest Commission for their assistance. They are grateful to the Japanese Government, through the Japan International Cooperation Agency (JICA), for the financial support.

\section{References}

Annan-Afful E., Iwashima N., Otoo E., Owusu-Sekyere E., Osafredu Asubonteng K., Kamidohzono A., Masunaga T. and Wakatsuki, T. (2004). Land Use Dynamics and Nutrient Characteristics of Soils and Plants along Topo-Sequences in Inland Valley Watersheds of Ashanti Region, Ghana. J. Soil Sci. Pl. Nutr. 50 (5): 633-647.

Brady, N. C. and Weil R. R. (2002). The Nature and Properties of Soils, 13th edn. Prentice Hall, Upper Saddle River, New Jersey.

Bray R. H. and Kurtz L. T. (1945). Determination of total, organic and available forms of phosphorus in soil. Soil Sci. 59: 39-45.

Brouwer L. C. (1996). Nutrient cycling in pristine and logged tropical rain forest. A study in Guyana. Tropenbos - Guyana Series 1: 145181. Printed by Elinkwijk, Utrecht.

Cuevas E. and Medina E. (1986). Nutrient dynamics within Amazonian forest ecosystems. I. Nutrient flux in fine litter and efficiency of nutrient utilization. Oecologia 68: 466-472.

Gong W. K. and Ong J. E. (1983). Litter production and decomposition in coastal hill dipterocarp forest. In Tropical Rain Forest: Ecology and Management. (S. L. Sutton, T. C. Whitemore and A. C. Chadwich, ed.), pp. 277-284. Special publications series of British Ecological Society. No. 2. Blackwell Scientific Pub., Oxford.

Hirose S. and Watkatsuki T. (1997). Nishi Africa. Savanna no Seitaikankyou no Syuhuku to Nouson no Saisei (Restoration of Ecology and Rural Life in Savanna Zone of West Africa), p. 484. Norin Toukei Kyokai, Tokyo (In Japanese).

ISSS (1994). World Reference Base for Soil Resources, pp. 161, draft, ISSS/ISRIC/FAO, New York.

John D. (1973). Accumulation and decay of litter and net production of forest in tropical West Africa. Oikos, 14: $430-435$.

Klinge H. (1974). Litter production in tropical ecosystems. Paper presented to IBP-Synthesis Meeting, Kuala Lumpur, Malaysia, 12-18 August, 1974.

Lugo A. E. (1991). Comparison of tropical tree plantations with secondary forests of similar age. Ecol. Monogr. 62(1):1-41. Ecological Society of America.

Manu A., Coleman T. L. and Juo A. S. R. (1997). Soil restoration in degraded agro-pastoral systems of semi arid West Africa. Proceedings of the Regional Workshop, Soil Fertility Management in West Africa Land Use Systems, University of Hohenheim, ICRISAT Sahelian Centre and INRAN, 4-8 March 1997, Niamey, Niger, pp. 176-177.

O’Neill R. V. and DeAngelis D. L. (1980). Comparative productivity and biomass relations of forest ecosystems. In Dynamic properties of forest ecosystem (D. Reichle, ed.), pp. 411-449. Cambridge University Press, Cambridge.

Owusu-Sekyere E., Cobbina J., Otoo E., Annan-Afful E., Masunaga T., Kubota D., Shimura T. and Wakatsuki T. (2003). Nutrient Dynamics in Disturbed Primary Forest in Dwinyama Watershed, Ashanti Region. Ghana J. For. 11: 1-9.

Proctor J., Anderson J. M., Fogden S. C. L. and Vallack H. W. (1983). Ecological studies in four contrasting lowland rain forests in Gunung Mulu National Park, Sarawak 11. Litterfall, litter standing crop and preliminary observations on herbivory. J. Ecol. 71: 261283.

SAS (1999). Using StartView, 3rd edn. Statistical Analytical System (SAS) Inc., Cary. 288 pp.

Swift M. J., Heal O. W. and Anderson J. M. (1979). Decomposition in terrestrial ecosystems. Studies in ecology, vol. 5. University of California Press, Berkeley, California.

Watson R. T., Noble I. R., Bolin B., Ravindranath N. H. and Verardo D. J. (2002). Land-Use and Forestry. http//www.grida.no/climate/ipcc/land-use. 